\title{
道路陥没の危険を探る
}

\section{—— 熱赤外線ビデオカメラが捉えた亀裂}

朝日航洋株式会社＼cjkstart荒木＼cjkstart春視

鹿児島県鹿屋市で道路が陥没して乗用車を飲み込ん でしまった，と言う新聞記事を読んだ。幸い乗ってい た人達は無事に救出された。しかし，記事は更に続い ていて，その陥没個所にダンプ車で土砂を運び，埋め 戻しにかかったが，投入土砂は地下の何処かに吸い込 まれてしまった，そうである。東京の銀座四丁目の交 差点でも，路面下に空洞が予想され，対応処置が実施 されたとの，マスコミ報道があった。最近，地下構造 物や地下埋設物の工事等では, 細心の注意を払われて はいるものの，埋め戻しが充分に行き届かない事もあ る。それが，後日，地下空洞の形成要因となり，道路 路面の陥没となって事故原因となる。また，地下空洞 は地盤沈下や地震等により地下構築物や埋設管が砂損
しても，そこで土砂移動が生じると，形成される。 道路路面下の空洞形成から路面陥没までの経過を, 熱分布の観点から時系列的に追ってみると，1）路面 下に空隌が形成され，2）空陌が拡大すると，上載荷 重に耐え切れなくなり，上部層に亀裂が生成される。

3) 亀裂が上方へと発達し, 路面にヒビ割れができる。 4) 地下空洞の拡大につれて, 亀裂幅が広がり, 亀裂 間に繫がりができ，亀裂は 2 次元に発達し，線状とな る。6）空洞が面的に拡大していくと, 路面での亀裂 分布も面的に広がる。7) 亀裂の発達状況は路面の温 度変化となって現れ, 通常, 日中に温まった路面が夜 間に泠える段階で，自然泠却作用による以上の温度低 下を亀裂発達部において生じる，こととなる。

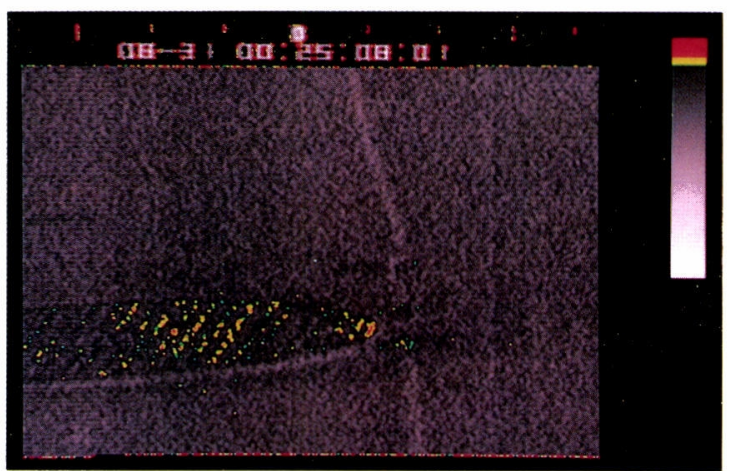

マンホール

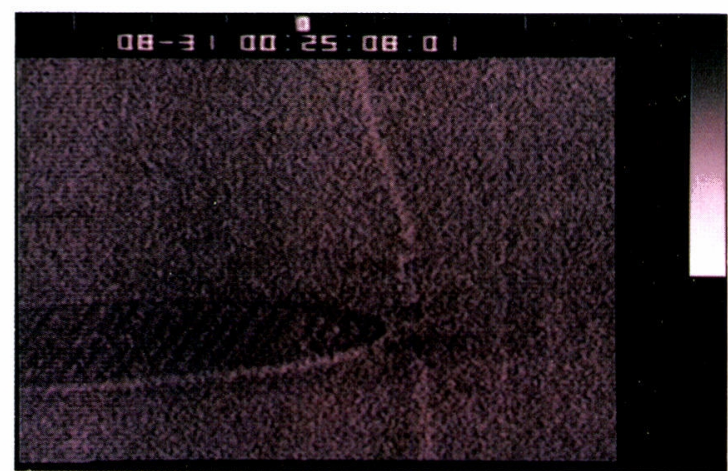

生画像

昭和63年 8 月 30 日の午後10時から31日の午前 6 時にかけて, 夜間における道路路面の温度画像を自動車に熱赤外線ビデ オカメラを搭載し, 時速 $20 \mathrm{~km} て ゙$ 撮影したものである。 


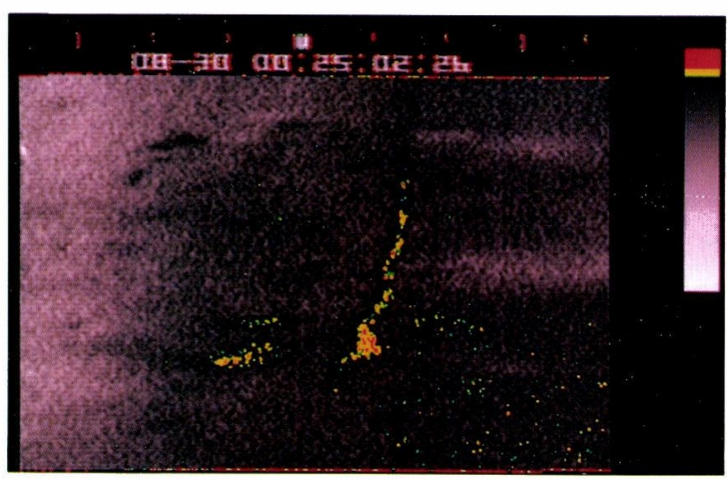

数 $\mathrm{cm}$ 幅の低温部が道路方向に $50 \mathrm{~cm}$ 長で発達するのに加え, 低温部が斑点状に数 $10 \mathrm{~cm} \times$ 数 $10 \mathrm{~cm}$ に広がる

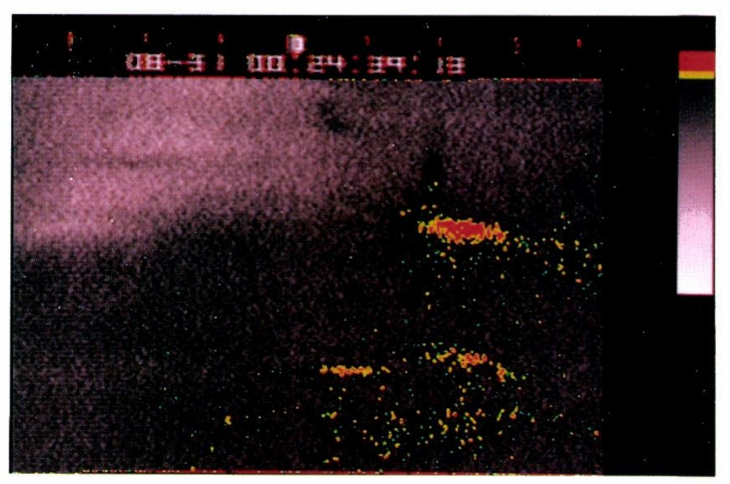

路面上で数 $10 \mathrm{~cm} \times$ 数 $10 \mathrm{~cm}$ の範囲に低温部が斑点状に発達 する。温度の特に低い部分もかなり広がる

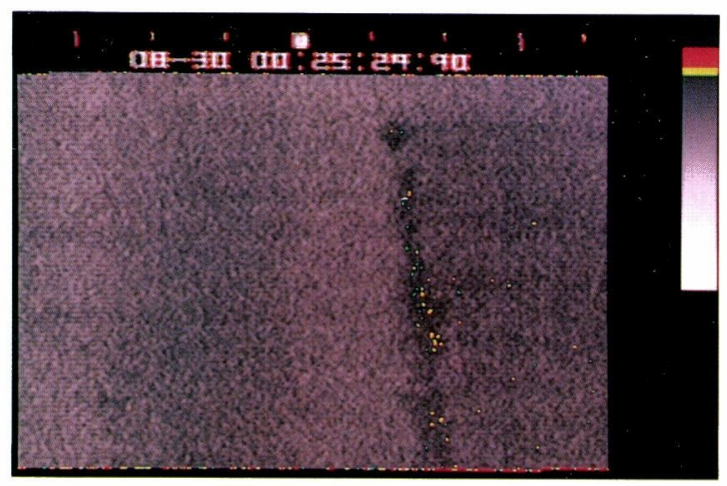

道路方向に沿い, 数 $\mathrm{cm}$ 幅で低温部が約 $1 \mathrm{~m}$ 伸びている

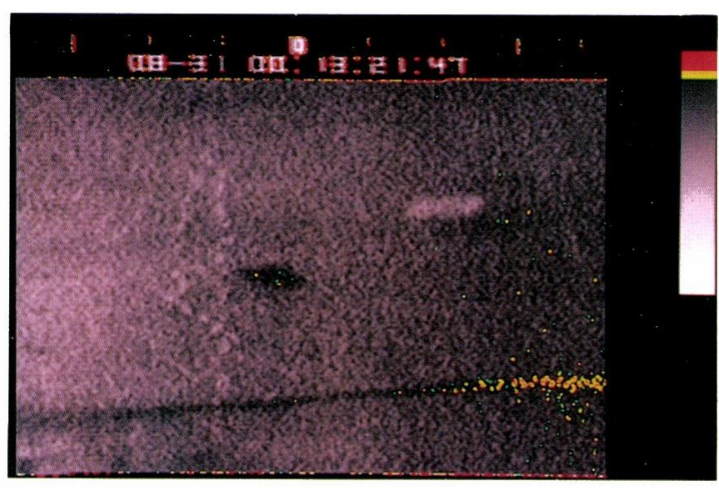

道路を横断して, 幅数 $\mathrm{cm}$, 長さ $1 \mathrm{~m}$ の低温部が発達する。 その中にも特に温度が低い部分がある

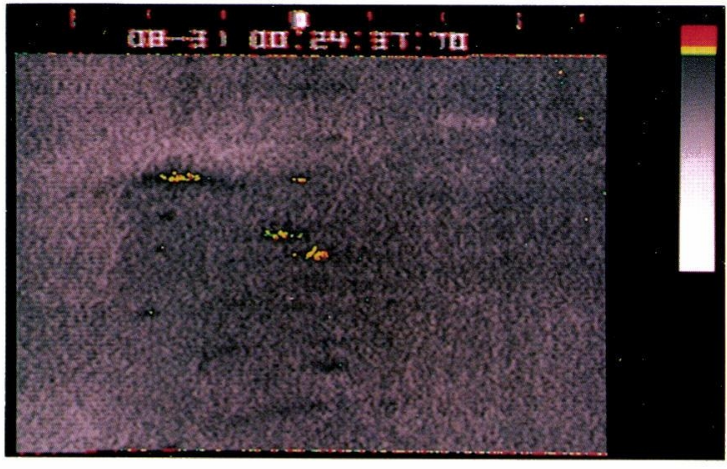

数 $10 \mathrm{~cm} \times$ 数 $10 \mathrm{~cm}$ 範囲に低温部が点在する。特に温度の 低い部分が, 幅数 $\mathrm{cm}$, 長さ $10 \mathrm{~cm}$ に広がる

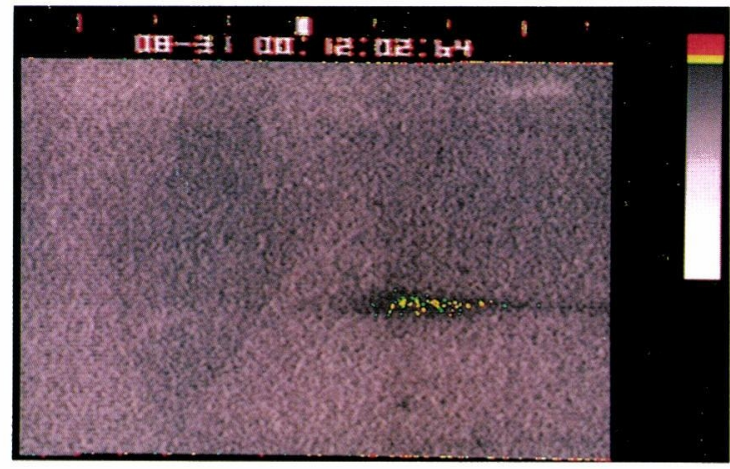

道路を横断して, 幅数 $\mathrm{cm}$, 長さ $1 \mathrm{~m}$ の低温部が線状に伸 びている。そのうちの長さ $30 \mathrm{~cm}$ が特に低い温度 